\section{Ruokakulttuuri kasvattaa kansaa}

Kylli, Ritva (2021). Suomen ruokahistoria. Gaudeamus. 525 sivua.

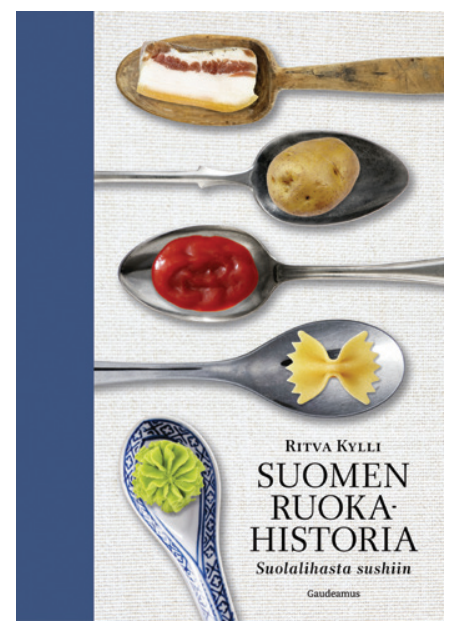

SUOMEN RUOKAHISTORIA On tuhti paketti tietoa ja viihdettäkin. Tyypillisenä akateemisena sekatyöläisenä aloitin teokseen tutustumisen lähdeluettelon selailusta, mikä vakuuttikin välittömästi ainakin taustatyön perusteellisuudesta. Lähteitä ja kuvalähteitä on listattu 20 sivua, ja niiden monipuolisuus huikaisee: mukana on tutkimuskirjallisuuden lisäksi runsaasti arkistolähteitä, lehtiä, keittokirjoja, mainoksia, kaunokirjallisia teoksia ja muistitietoa. Lähdemateriaalia myös avataan lukijalle. Se lukija, jota erityisesti kiinnostaa jonkin tietyn ruokalajin historia, hyötyy kirjan lopussa olevasta kattavasta aakkosellisesta ruokahakemistosta.

Kirja kuljettaa lukijansa aina keskiajalta vuosituhannen vaihteeseen tarjoillen perinpohjaisen, kronologisen faktatiedon ohella lusikallisia tai peräti kauhallisia mielenkiintoisia yksityiskohtia aikalaiskuvausten, sananparsien ja anekdoottien muodossa. Leipätekstiä elävöittävät ilmiöitä kuvaavat tietolaatikot, muun muassa leivästä ravinnon lähteenä, marjoista, keittoastioiden ja ruuanlaittovälineiden kehityksestä ja sushin Suomen-valloituksesta. Kuvitus on runsas ja monipuolinen.

\section{LÄHTEET MÄÄRITTÄVÄT PAINOPISTEEN}

Vaikka teos kattaa pitkän ajanjakson Suomen historiasta, sen pääpaino on parin viime vuosisadan ruokakulttuurissa, mikä saatavilla olevien lähteiden valossa on ymmärrettävää. Kuvaukset keskiajan ja varhaismodernin eli 1500-1800-lukujen suomalaisesta ruokakulttuurista nojaavat pitkälti esimerkiksi ajalta säilyneisiin tilikirjoihin tai muihin arkistolähteisiin.

Hieman harmillisesti aikajanan toisessa päässä 2000-luvun ruokakulttuuria on mahtunut teokseen vain nimeksi. Koronapandemian keskellä esimerkiksi kirjassa siteerattu ruokatoimittaja Eeva Salosen toteamus itsepalvelumyymälöistä vuodelta 1983 saa suorastaan messiaanisen sävyn: "Ajatusrakennelmaa seuraten voisi kuvitella tulevaisuutta, jossa itse kukin meistä tekee työtä kotona ja sisällöltään ohjelmoitu ostoskori saapuu suoraan kotiin. Sellaista tuskin kukaan haluaa." (s. 377).

1900-luvulle tultaessa voidaan todeta, että Suomen ruokahistoria on monipuolinen kattaus ajan kulttuurihistoriaa - tosin ravitsemuksen näkökulmasta. Kirjassa perehdytään niin sairaaloiden, koulujen kuin vankiloiden ruokatarjontaan ja aatteisiin niiden taustalla. Sodanaikaisista sotilaiden muona-annoksista, samoin kuin siitä, mitä riitti ruuaksi kotirintamalla, saadaan seikkaperäinen kuvaus.

Erityisen kiinnostava osio kertoo evakkojen ja paikallisten toisistaan poikkeavista ruokatottumuksista ja siitä, miten ruokakulttuurien yhteentörmäys lopulta on rikastuttanut molempia osapuolia. Evakkojen kohtaamista ennakkoluuloista onkin helppo vetää yhtäläisyyksiä nykypäivän monikulttuuristuvaan Suomeen.

\section{TIE VALISTUKSEEN KÄY KEITTIÖN KAUTTA}

Valistus on näytellyt merkittävää osaa suomalaisessa ruoka- ja juomakulttuurissa, mistä kärjekkäin esimerkki on vuosien 1919-1932 kieltolaki. Raittiusliikkeen onnistui muun muassa leimata ravintolat vaarallisiksi paikoiksi, mikä aiheutti hankaluuksia koko alalle. Mutta jo ennen kieltolakia valistus rantautui Suomeen Yhdysvalloissa kehitetyn kotitaloustieteen muodossa.

Valistuksen merkitystä ei kirjassa käsitellä omana ilmiönään, mutta se nivoutuu luontevasti kerrontaan aihepiireittäin, esimerkiksi luvussa "Vitamiinit kotirau- 


\section{VALISTUS NIVOUTUU LUONTEVASTI KERRONTAAN}

\section{AIHEPIIREITT ÄIN.}

han häiritsijöinä” (s. 216-226). Samoin vuonna 1972 käynnistynyt suolaa, rasvaa ja tupakanpolttoa karsimaan pyrkinyt PohjoisKarjala-projekti esitellään suomalaisen terveysvalistuksen tärkeänä etappina.

Kaikista valistuksen ponnisteluista huolimatta teoksessa on monin paikoin havaittavissa, että Suomen ruokahistoriassa toistuu liharuuan ihannointi ja epäluulo kalaa ja kasvisruokaa kohtaan tämän päivän somekohut eivät siis tuo esiin mitään uutta auringon alla. Muun muassa sota-ajan armeijamuonituksesta todetaan: "Lihan syöminen on yhdistetty voimaan ja viriliteettiin, eikä sotaaikanakaan haluttu altistaa joukkoja liian epämiehekkäälle syötävälle” (s. 301).

\section{LAAJOISTA KAARISTA KNOPPITIETOON}

Seikkaperäisen kulttuurihistorian kaaren ohella Suomen ruokahistoria tarjoaa lukijalle runsaasti kiinnostavaa ja yllättävääkin knoppitietoa. Tiesitkö esimerkiksi sitä, että keskiajalla Suomessa syötiin kalan, leivän ja puuron ohella yhtä tämän päivän trendiruokaa, eli härkäpapuja? Tai että 1800-luvun lopulla annettiin asetus, jonka mukaan kestikievareissa ei tarjoiltu paikkakuntalaisille alkoholia? Ja että Ruotsi järjesti kieltolaista kansanäänestyksen vuonna 1919, ja "ei" voitti? Uutta tietoa on sekin, että edelleen käytössä oleva sana jäkakappi juontaa juurensa ajalle, jolloin ruokaa viilennettiin kaapissa jäälohkareiden avulla. Entäs se, että 1950-luvulla ylivoimaisesti suosituin ravintola-annos oli sipulipihvi, ja sen jälkeen nakit muusilla?

Keittokirjojen suurena ystävänä ja niiden kääntämisen tutkijana jäin kaipaamaan enemmän mainintoja siitä, miten muiden kulttuurien ruokavaikutteita on aikojen saatossa kulkeutunut maahamme suomeksi ja ruotsiksi käännettyjen keittokirjojen, ja viime vuosikymmeninä enenevissä määrin televisio-ohjelmien tai verkon kautta. Tekijä tosin toteaa, että keittokirjojen tarjoama lähdeaineisto vaatii paljon lähdekriittisyyttä: "Suomessa ilmestyneet keittokirjat kertovat periaatteessa hyvin havainnollisesti kyseisen aikakauden ruokailutottumuksista ja jokapäiväisestä ruoanlaitosta, mutta toisinaan ne ovat olleet edellä aikaansa ja kertoneet ehkä enemmän siitä, minkälaisia ruokia suomalaisten olisi haluttu valmistavan”. (s. 17).

Suomen ruokahistoria on kaiken kaikkiaan ihastuttava teos, jossa tinkimätön ja perusteellinen akateeminen tutkimusote yhdistyy viihdyttävään kerrontaan. Teosta voi lämpimästi suositella kaikille ruuasta ja historiasta kiinnostuneille ajankuluksi, mutta yhtä lailla myös kurssikirjaksi eri asteiden oppilaitoksiin.

\section{MARI PAKKALA-WECKSTRÖM}

FT, dosentti, englannin kääntämisen yliopistonlehtori kielten osasto humanistinen tiedekunta Helsingin yliopisto

(D) https://orcid.org/0000-00028707-9561 